\title{
UNDERSTANDING ECONOMIC INEQUALITY THROUGH THE LENS OF CASTE
}

\author{
Hari Bapuji ${ }^{1}$ \\ Faculty of Business and Economics \\ The University of Melbourne, Victoria 3010 Australia \\ E-mail: hari.bapuji@unimelb.edu.au \\ Phone : +61-3-8344-9867

\section{Snehanjali Chrispal} \\ Faculty of Business and Economics \\ The University of Melbourne, Victoria 3010 Australia \\ E-mail: snehanjalia@unimelb.edu.au
}

Forthcoming in Journal of Business Ethics

Running Head: Caste and Economic Inequality

Funding: None

Conflict of Interest: The authors declare that they have no conflict of interest.

\section{ACKNOWLEDGEMENTS}

The authors would like to thank the handling editor Prof. Raza Mir and the anonymous reviewers for their insightful comments and helpful suggestions. The authors would also like to thank W.E. Douglas Creed, Krishna Udayasankar, Charlene Zietsma, and Michael Zyphur for their helpful comments on earlier versions of this article. This paper also benefitted from the comments of participants of Organisation Studies Research Workshop at the University of Melbourne, as well as anonymous reviewers of AOM and IABS conferences. The authors express their gratitude to all of them.

${ }^{1}$ Corresponding author 


\title{
Understanding Economic Inequality through the Lens of Caste
}

\begin{abstract}
Research on economic inequality has largely focused on understanding the relationship between organizations and inequality but has paid limited attention to the role of institutions in the creation and maintenance of inequality. In this article, we use insights from the caste system - an institution that perpetuates socio-economic inequalities and limits human functions - to elaborate on three elements of economic inequality: uneven dispersions in resource endowments, uneven access to productive resources and opportunities, and uneven rewards to resource contributions. We argue that economic inequalities persist because these three different elements of inequality feed from and reinforce each other. Our study underscores the potential of the caste lens to inform research on economic inequality as well as organizational theory and practice.
\end{abstract}

Keywords: Caste system, Economic inequality, Income inequality 
Rising economic inequality around the world, particularly in the developed world, has been a longstanding area of scholarly inquiry in non-business disciplines (Marsh, 2016; McCall and Percheski, 2010; Neckerman and Torche, 2007; Piketty, 2014; Wilkinson \& Pickett, 2009). Business organizations not only generate and maintain inequality, but are also affected by its consequences (Alamgir \& Cairns, 2015; Andrews \& Htun, 2017; Bapuji, 2015; Bapuji \& Neville, 2015; Bapuji \& Mishra, 2015; Jiang \& Probst, 2017; Muckenhuber, Burkert, Großschädl $\&$ Freidl, 2015). Therefore, organizational researchers have recently turned their attention to income inequality to understand how organizations contribute to income inequality, and are, in turn, affected by it (Beal and Astakhova, 2017; Cobb, 2016; Davis and Cobb, 2010; Fotaki and Prasad, 2015; Leana and Meuris, 2015). A number of journal special issues on the topic of economic inequality have firmly placed the topic in the domain of organizational scholarship (Bapuji, 2015; Bapuji, Husted, Mir \& Lu, 2018; Suddaby, Bruton \& Walsh, forthcoming).

This burgeoning scholarship on economic inequality has begun to advance theories on how corporations contribute to income inequality by facilitating economic exchanges (Bapuji, Husted, Mir \& Lu, 2018; Beal, Astakhova \& Conaway, 2017; Cobb, 2016), and by shaping the institutional environments within which those exchanges take place (Beal and Astakhova, 2017; Beal et al., 2017). It has also begun to theorize how inequality affects the institutional environment, in which corporations operate (Bapuji, 2015; Bapuji \& Neville, 2015; Shrivastava \& Ivanova, 2015; Reinecke, forthcoming). This research has not, however, paid adequate attention to examine how particular institutions in a society affect economic inequality.

Studying economic inequality from an institutional perspective can yield important insights to improve our understanding of inequality by complementing an organizational perspective. For example, an organizational perspective focuses more on economic factors and 
financial dimensions of inequality, such as wealth and income. In contrast, an institutional perspective can unearth the non-economic and non-financial aspects of inequality rooted in the sociocultural context of the society. Also, while an organizational approach identifies the organizational strategies that contribute to income inequality in a society, an institutional approach can shed light on the institutional forces that affect those organizational strategies (Davis, 2017). Similarly, inequality is affected by the logics through which existing institutions are maintained, the identities that current institutions engender, and the everyday social and organizational practices that legitimize inequalities (Amis, Munir \& Mair, 2017).

In addition to paying limited attention to the role of institutions in inequality, previous research has also paid less attention to theorizing the construct of economic inequality. Although extant definitions of economic inequality allude to uneven dispersion in resource possession and access (Bapuji, 2015; Haack \& Sieweke, 2018; Mair, Wolf \& Seelos, 2016), these definitions have rarely been contextualized, and the relationship between the elements of possession and access has not been theorized. Further, scholars often use economic inequality interchangeably with income inequality and wealth inequality, thus pointing to the need to clarify and elaborate what economic inequality is.

In this paper, we examine the caste system as an institution to understand how it perpetuates socioeconomic inequalities. We then use this understanding to elaborate on three different elements of economic inequality: uneven dispersion in endowments of resources, access to resources, and rewards to labour (Bapuji, 2015). Specifically, we clarify (i) the financial and non-financial nature of resources that create and maintain inequality, and (ii) highlight the interlinkages between resource endowments, access to productive resources and opportunities, and rewards to productive resources. These interlinkages perpetuate socioeconomic inequalities 
in a society by giving better access and higher rewards to those with greater resource endowments. Accordingly, we seek to refine and enrich the construct of economic inequality to better capture its complexity and nuance.

This paper makes two important contributions to organizational research. First, despite the emergence of a vibrant stream of research on economic inequality, current understanding of the construct of economic inequality is limited. Our examination of this topic builds on the earlier definitions of economic inequality to enhance conceptual clarity. Specifically, we (i) elaborate on the various types of resources, and (ii) highlight the interlinkages between resource endowment, access and rewards, which serve to perpetuate economic inequality. Further, we adopt an institutional approach to economic inequality and highlight the potential ways in which institutional theory can benefit from studying economic inequality, particularly institutions such as the caste system. Second, the caste system affects the socio-economic lives of over a billion people in the Indian subcontinent and its diaspora spread around the world, whose caste practices have come under increasing scrutiny in recent times. Although management researchers have often used caste as a demographic attribute, they have devoted little attention to examining caste as an institution and its consequent effect on individuals and organizations. This paper brings a caste lens into the discourse on organizations and institutions, and highlights the potential of the caste lens to inform future research on inequality, as well as inform the organizational research more broadly.

The remainder of this paper is organized as follows. We first describe the caste system as an institution by outlining its features and relevance to everyday life. We then discuss how the caste system affects economic inequality by influencing resource endowments, resource access, and resource rewards in conducting economic exchanges. Later, we conceptualize the 
interrelationships between the elements of economic inequality and explain how those interrelationships perpetuate economic inequality. Finally, we discuss the implications of our study to organizational research and practice.

\section{ECONOMIC INEQUALITY AND THE CASTE SYSTEM}

Economic inequality is an area that warrants organizational research because firms are central to wealth creation in a society and thus have an undeniable role in societal economic inequality (Bapuji, 2015). Accordingly, organizational research has predominantly focused on studying the organizational antecedents of income inequality. For example, Cobb (2016) argued that firms contribute to labour income inequality at the societal level through their organization of firm boundaries, matching of individuals to jobs, and rewards to employee labour. Specifically, empirical evidence showed that as the proportion of individuals employed by large corporations decreases, income inequality increases (Cobb \& Stevens, 2016; Davis \& Cobb, 2010). Also, decreased wage premiums for employees at the lower and middle levels in large organizations has contributed to income inequality (Cobb \& Lin, 2017). Taking a broader view of income inequality, at the societal level, Bapuji et al. (2018) argued that value distribution mechanisms that follow the shareholder wealth maximization principle contribute to income inequality by handsomely rewarding executives and shareholders, and giving a short shrift to employees, government and the society at large.

While the distribution of rewards by firms explains income inequality at the societal level, it is the national-level institutions that shape the type of organizations and their approaches to the distribution of rewards (Davis, 2017). More broadly, inequality is created and maintained by entrenched power structures, which are manifested as institutionalized norms and beliefs that affect socioeconomic lives of individuals within and outside firms (Amis et al., 2017). 
Particularly, Amis et al. (2017) suggested that useful insights can be generated by studying the microfoundations of inequality, i.e., how inequality is enacted and experienced through everyday habitual actions. In short, there is an emerging view that an institutional approach to studying economic inequality can provide insights into how economic inequalities are created and maintained.

In addition, by focusing predominantly on organizations, research on economic inequality has limited the understanding of the construct. Although scholars have used the term 'economic inequality' to refer to various types of inequalities (e.g., gender, racial, and ethnic), they have primarily equated economic inequality with income inequality and wealth inequality, often interchangeably. The inequalities of wealth and income do not fully capture the inequalities that affect an individual's socioeconomic life (Bapuji \& Mishra, 2015). Echoing this argument, some scholars have defined inequality as "the uneven distribution of economic resources, such as income and wealth, as well as, of other social resources, such as information and social integration, which contribute to income or wealth as intervening variables" (Haack \& Sieweke, 2018:2).

Some researchers have argued that economic inequality should be concerned with equality of opportunity to do and be what one wants to $^{2}$, particularly considering individual heterogeneities in capabilities, needs and preferences (Neckerman \& Torche, 2007; Sen, 1997). In a similar vein, Mair, Wolf and Seelos recognized that inequality "manifests in unequal access to opportunities and rewards for different social positions or statuses within a group or society, and it is rooted in socially constructed categories (such as gender, caste, or class) that determine

\footnotetext{
2 Equality of opportunity or equal access is often considered as equity in non-business literatures. However, organizational researchers have used equity to refer to disparities in rewards. For a discussion on this, please see Alamgir \& Cairns, 2015 and Bapuji \& Mishra, 2016.
} 
boundaries for inclusion and exclusion and demarcate positions of power and privilege" (2016:2021). Taking a somewhat overarching view, Bapuji defined economic inequality as the "uneven dispersion in resource endowments, access to productive resources, and rewards for labour in a social collective that limits the fulfilment of human functions" (2015:1061). In short, current descriptions of economic inequality touch upon various aspects, including resources, rewards, opportunities and social structures, but have not clarified and elaborated on the elements of economic inequality.

To advance an institutional approach to study economic inequality and to enrich our understanding of economic inequality, we focus on the caste system predominantly found in the Indian subcontinent. India is unique in its complexity and diversity, yet it is characterized by the prevalence of social structures like the caste system. People who share a cultural context tend to construct shared frames that distinguish identities. This, in turn, builds an affinity toward other members who share these identities (Banerjee, 2003). Institutions shape and construct these identities, subjecting individuals to existing norms, practices and regulations. These persisting characteristics of social life give stability to institutions over space and time (Giddens, 1984).

Institutions are those innate and irrepressible facets of social structures that continuously rationalize values, rules, norms and behaviours in a given social context (Thornton \& Ocasio, 2008). As we elaborate later, the caste system influences every aspect of socioeconomic life in the Indian subcontinent and elsewhere, through prescriptions that prohibit and restrict actors in particular social arrangements. This aligns with Weber's view that keeping systems of rules constant is an attempt to maintain structures of domination; however, even changing those systems only further modifies structures of domination (1905). The caste system, as an institution, determines the "rules of the game"; human interaction is constrained by humanly devised 
restrictions (North, 1990); and is edified by normative, regulative and cognitive structures and activities that reproduce social behavior and also provide meaning to it (Scott, 1995).

The caste system limits the fulfilment of human functions because caste greatly influences, if not determines, the social interactions between individuals, the economic activities they conduct, and the economic transactions between them. Both scholarly and non-scholarly accounts point out that although caste has been outlawed, it continues to be a potent force in the Indian subcontinent - defining individual identities and socioeconomic interactions (Agrawal, 2016; Cotterill, Sidanius, Bhardwaj \& Kumar, 2014; Dar, 2018; Mair et al., 2016; Thekaekara, 2016; Vissa, 2011). Therefore, studying the caste system can not only inform how institutions influence inequality, but can also enrich our understanding of the construct of economic inequality, its elements and the relationships among them. In other words, our effort is to use the caste system as a lens to better understand the construct of economic inequality and to generate a preliminary understanding of how institutions like caste influence inequality. Toward this end, in the next section we briefly describe the caste system to introduce it to readers unfamiliar with it and discuss how its features influence social life of individuals under it.

\section{Features of Caste System and their effect on Social Life}

Originating from the Portuguese term 'casta', or something that is pure, "caste" was used by invaders of India in the $16^{\text {th }}$ century, to refer to the social stratifications that existed among the inhabitants of the Indian subcontinent (Saha, 1993). While foreigners saw caste ${ }^{3}$ as a unique

\footnotetext{
${ }^{3}$ Although some scholars have tried to merge the concepts of Caste and Class, such efforts ignore the intricacies that make them distinct from each other. Both caste and class allude to stratifications in society, but they segregate groups in different ways. While the caste system is legitimized through ritualistic authority, the class system is solely based on wealth and power (Dumont, 1980). However, some scholars have argued that social stratification is only one feature of class (Hyman, 2006). Class in society is established on the construction of identity and social significance of diverse economic groups through the conflicts and relationships between them, reconciling the “'objective' and 'subjective' dimensions of class structure" (Hyman, 2006:33). While certain aspects of caste system manifest in society similar to the class system, its primary distinction is the segregation based on the sacred, ritualistic and ethnic differences. Another divergence between class and caste is social mobility (Mondal, 2014). An
} 
phenomenon, members of Hindu society, who practiced it, particularly the upper castes, did not reflect its novelty, but rather justified the stratification as merely a tool of organization (Srinivas et.al, 1959; Lenski, 2013). This hierarchical caste system, rooted in the conceptualization of the varnas $^{4}$ (meaning colours or categories), was attributed to early writers of the distant past, typically Brahmins - those at the apex of the caste system (Saha, 1993).

The Brahminical model suggests that Brahma - the Hindu god of Creation, created people of four different types from his own body: Brahmins from his head/mouth, Kshatriyas from his arms, Vaisyas from his thighs, and Sudras from his feet. This creation formed the basis for a social hierarchy, which is the first feature of the caste system. At the top of the caste hierarchical order are the Brahmins, or the priests and scholars. They are followed by the Kshatriyas, who are the political leaders and warriors. Next in the social order are the Vaisyas, who are the merchants and traders. The Sudras, the fourth caste, are the laborers, artisans, and servants (Deshpande, 2010).

The social architecture of the four-tiered varna system did not include those at the peripheries, the untouchables, or Dalits ${ }^{5}$. The status of Dalits is justified by Hindu religious texts, where they are seen as 'polluted' and 'unclean' (Grey, 2005). Another category that did not find place in the caste system is the Adivasi, or indigenous tribal groups whose social organization was away from the village-based organization of the caste system.

individual may be born into particular social class, but there is no restriction to mobility to other classes. Such mobility might be hard, but is not impossible. On the other hand, upward mobility in caste is impossible even when "lower" castes pursue non-traditional occupations or achieve political and economic power. Further, the caste system is organic and biological, while class is 'segmentary', where divisions of class are driven by competition (Mondal, 2014; Leach, 1960).

4 Throughout this paper, we italicize many words that have an origin in Sanskrit language and provide their approximate English equivalent or a brief description as necessary.

5 The term Dalit is a recent invention. In the past, they were called achoot or untouchables. During the Indian freedom struggle, Gandhi attempted to alleviate untouchability by referring to them as harijans (meaning the children of God). This imposition of a label was resisted by Dr. Ambedkar, a Dalit social reformer and politician, who renamed "Untouchable" to "Dalit" or the oppressed. 
The top three castes (Brahmins, Kshatriyas and Vaisyas) together are called the savarnas or "upper" castes. In terms of population percentages, these three castes as well as other castes classified as forward castes represent about $31 \%$ of the population. Sudras, known as Other Backward Castes, constitute $40 \%$ of the population, while Dalits are $20 \%$ of the population, and Adivasis constitute $9 \%$ of the total population (Deshpande, 2010) ${ }^{6}$. These main castes or varnas are further divided into thousands of sub-castes or jati, each pertaining to a particular occupation.

While positioning an individual in a social hierarchy is the first feature of the caste system, the second is restricted upward mobility, which aimed to maintain the ritualistic purity of the caste (Strauss, 2017). An individual's position in the hierarchy is determined by birth, typically based on a patriarchal lineage. Such position was justified on the grounds that it emerged as a result of one's deeds in previous births and, deeds in the current birth would determine the individual's caste in the next birth. Consequently, position and mobility are nonnegotiable; nothing an individual does in this life will affect their current status and position. However, some scholars contend that some mobility within the middle and upper regions of the caste system can occur through sanskritization, which refers to the adoption of a Brahminical way of life, which includes vegetarianism, teetotalism, and the related rituals and philosophies of life, while at the same time, breaking contact with and shunning other subaltern castes (Srinivas et.al, 1959). Through such adoption, some categories of people were able to successfully gain some social mobility in a span of few generations, while others were less successful ${ }^{7}$.

\footnotetext{
6 Reliable data on population shares of various castes are not available because the census data has not been made public. Also, castes are clubbed together for various purposes. For example, both upper castes (i.e., brahmins, kshatriyas, and vaisyas) and a number of castes that have better socioeconomic standing have been termed as forward castes for the purposes of affirmative action.

7 While "lower" castes seek mobility through sanskritization, "upper" castes seek social mobility through westernization. For example, the orthodox Brahmin's perception of western norms is associated with ritual impurities; however, the western world is economically and politically powerful, thus, making them imitable (Saha, 1993). This accounts for Brahmins' accommodation of western culture and practices to remain relevant in modern society.
} 
In contrast to this potential mobility within the middle and upper regions of the caste system, mobility was not possible for the Dalits and other "lower" castes. For example, Dr. Ambedkar, a Dalit social reformer and politician credited with writing the Indian constitution, began the Dalit Buddhist Movement and asked Dalits to convert to Buddhism to escape the oppression of the Hindu social order (Chirakarode, 1993). However, when these Dalits went back to their villages, they were constrained to the same jobs and experienced tremendous persecution from the upper-castes. Those who had converted to Christianity and other religions also faced a similar situation. In other words, religious conversions did not offer mobility or escape from the caste system. Instead, the caste system permeated to other religions, such as Islam and Christianity.

Third, the caste system determined social interactions, particularly relations by marriage (Scott, 1987). To maintain the ritualistic purity of caste, individuals practiced endogamy and were restricted from marrying outside of their caste. For each caste, the rules pertaining to marriage included differences in dowry payments, timings, rites and rituals and so forth (Akerlof, 1976). Women are the gateways to the caste system - they preserve the purity of the caste through marriage and children; therefore, "lower" caste men are seen as a threat to "upper" caste purity and kept away from them (Chakravarti, 2012). Some characterized this as an attempt of the Brahminical dogmas to instigate caste propagations by repressing the polluting of castes and reducing the mixing of castes (Chakravarti, 2012). Those who did not maintain the purity of the caste were then shunned and deemed outcastes (Akerlof, 1976). This shunning and out-casting could range from excommunication from the village to punishments in the form of maiming and killing, which are ironically dubbed 'honour killings' ${ }^{8}$.

\footnotetext{
8 According to National Crime Records Bureau of India, there were a reported 71 cases of such killings in India in 2016. However, Honour Based Violence Awareness Network estimates that 1,000 such killings occur in India each year, while 5,000 occur around the world.
} 
Fourth, in addition to endogamy, the milieus of caste minimize and control the social intercourse between individuals of different castes (Ghurye, 1932; Munshi, 2017). In a village, this is achieved by the allocation of land and regulation of the construction of houses, such that people of various castes are housed together and do not come in contact with others, except when necessary. For example, the houses of Brahmins would surround the temple and school, and were located at the centre of the village. The houses of Shudras would be at the edge of the village, clustered according to their occupations. Away from the village, at a considerable distance, lay the houses of Dalits. Such restrictions on housing created physical distances between members of different castes, and also ghettoized Dalits by confining them to village outskirts (Munshi, 2017).

While the layout of the village helped to minimize interaction among the castes, scriptures and norms also provided guidelines on how to interact with "lower" castes, particularly Dalits, if such interaction became necessary. For example, if "upper" caste and "lower" caste people happened to come face-to-face, the "lower" caste people were expected to move to the side and stand with a bowed head. Dalits were required to carry a broomstick to clean the place before and/or as they left. In commercial establishments, utensils used by "lower" caste people were maintained separately from those used by others to avoid 'contamination'. For example, it is not uncommon - even today, in some villages - to serve food or tea for Dalits in separate containers that are never mixed with those used by others. Upon using them, Dalits were required to wash and clean those containers. This system is known as the "two-tumbler" system. In other words, despite modernization, caste system and untouchability are still practiced by a considerable portion of the Indian population and Indian diaspora (Chisti, 2014; Metcalf \& Rolfe, 2010; Zwick-Maitreyi, Soundararajan, Dar, Bheel \& Balakrishnan, 2018). 
The discussion above points to the rigidness of the caste system and its determination of an individual's social status and social life, solely based on one's birth. As the caste system is very complex, it is not possible to articulate or present all its features in a generalizable fashion. However, the predominant features we presented above - positioning of individuals in a hierarchy based on birth, restricted upward mobility, endogamy, and control of social interactions among castes - are important to understand the manner in which the caste system creates and maintains inequalities. The complex and multifaceted nature of the caste system enabled it to persist despite attempted reforms, particularly affirmative action-style reservations for "lower" caste students and workers in public institutions, which we briefly discuss below.

\section{Mobility Enhancement Initiatives}

The affirmative action program or the reservation system created by the Indian government has been an important intervention aimed at improving the socioeconomic mobility of "lower" castes. This program has allocated certain positions in politics, education, and government for individuals from underprivileged castes (Hoff, 2016; Munshi, 2017). These castes were categorized as (i) scheduled $\operatorname{castes}^{9}$ (SC), which included all castes that were previously considered as untouchable and now known as Dalits, (ii) the scheduled tribes (ST) were the indigenous tribes and now known as Adivasis, and (iii) Other Backward Castes (OBCs) who were from the Sudra category (Hoff, 2016).

Despite the allocation of nearly 50 percent of seats in educational institutions and jobs in the government to the "lower" castes, their presence in the higher echelons of these institutions is scarce (Kumar, 2017). For example, in IIT Kanpur, a premier institute of technology in India, less than one percent of teaching staff ( 3 out of 394) belonged to the SC, ST, and OBC

\footnotetext{
${ }^{9}$ Census conducted during the British colonial rule have arguably codified and formalized the numerous sub-castes (jatis) into various schedules, a practice that continued in Independent India.
} 
categories. In contrast, nearly 45 percent (or 280 out of 629) non-teaching staff such as cleaners and assistants, belonged to the SC, ST, and OBCs (Jha, 2017). This evidence indicates that the system of reservation is somewhat effective at the low-skilled jobs, but has not made a difference in the high-skilled jobs.

While affirmative action programs are constructed to enable socioeconomic mobility of "lower" castes, they can further entrench the chasms of inequality and rigidify social identities. Those individuals with a tenacious social identity tend to fixate on the group and the elements that connect them to that group (Laar et. al, 2008). Further, reservations can stigmatize receivers and hinder their outcomes (Laar et. al, 2008). The SC/ST (Dalits and Adivasis) have recounted a myriad of examples from their experiences, where they were questioned about their caste identities, berated by employers due to reservation policies, and exposed to contempt and aggravation (Deshpande, 2013).

The discrimination faced by Dalits and Adivasis in educational and economic establishments can be a result of the opposition to affirmative action programs, which has roots in intergroup conflict (Blumer, 1958; Bobo, 1998; Lowery et.al, 2006). This conflict occurs because individuals from one group (dominant groups) are inclined to maximize their own outcomes compared to other rival groups (minority groups), thus widening gaps in education, access to jobs, and other socioeconomic resources (Lowery e.al, 2006). Evidence also suggests that these individual divergences in motivations for hierarchy result in antagonism toward policies seeking to mitigate social inequality (Lowery e.al, 2006).

Like other systems of discrimination, the caste system hinders market efficiency and individual mobility, but the collective networks created by the system are so entrenched that individuals abstain from acting alone (Hoff, 2016). Caste is an institution where conformance of 
an individual is pertinent to the conformance of the group. This influence on the cognition of individuals only solidifies the stratifications; this vicious cycle is maintained as "people construct institutions, and institutions continue to shape understandings" (Hoff, 2016:9).

In sum, the Indian caste system provides a clear and demonstrable example of the manner in which institutions in a society influence the social status and social life of an individual. This influence creates and maintains societal inequalities. At first glance, the caste system appears to be one of social organization, but it is also a system of allocation and control of economic resources, which has a more direct effect on economic inequality. We turn our attention to how the caste system affects economic lives of individuals and thus engenders economic inequalities.

\section{EFFECT OF THE CASTE SYSTEM ON THE ECONOMIC LIVES OF INDIVIDUALS}

Caste identity shaped (and continues to shape) the economic lives of individuals in fundamental and sedimented ways by determining the occupations that they had access to (Qureshi, Sutter \& Bhatt, 2017). The “upper” castes were provided the high-paying, 'upper-rung' occupations (Deshpande, 2001). Brahmins were given occupations as priests, scholars, educators, ministers, and advisors. More generally, only Brahmins were allowed to pursue any occupation that depended on knowledge (Ilaiah, 2009). Kshatriyas pursued roles as kings, ministers, administrators, soldiers, and land owners. Vaisyas were merchants and traders, while Sudras were given occupations that involved skill and dexterity, such as blacksmithing, goldsmithing, carpentry, pottery, and masonry (Saha, 1993). Dalits were confined to occupations that involved cleaning and sanitation: removing dead carcasses, sweeping streets, cremating the dead, clearing sewers, cleaning toilets, and carrying human waste and disposing it off. As a result of the caste-based assignment of occupations, $72-73 \%$ of the total population was relegated to 
job categories that included "farm, fish, hunt, log” or other 'lower-rung' occupations (Deshpande, 2001).

By assigning people to occupations based on birth and by ensuring the hierarchy, the caste system provided "upper" castes with a near-exclusive control over resources, which in turn ensured their dominance in economic activities. We discuss this inequality by examining three elements of economic inequality: endowment of resources, access to resources, and rewards to labour (Bapuji, 2015).

\section{Endowment of Resources to Different Castes}

The distribution of resources critical to production processes -financial and non-financial resources, as well as tangible and intangible resources - was typically based on the caste one was born into. The disparities in possession of wealth were particularly visible in the caste system. In a study conducted over the years 1991-2002, it was found that the relative median wealth of individuals from "upper" castes was substantially higher than their "lower" caste peers in both urban and rural India. Individuals from scheduled tribes and scheduled castes were significantly deprived of wealth in comparison to the other castes, and that trend has only worsened over the years (Zacharias \& Vakulabharanam, 2011).

Land, the primary resource of production in an agrarian economy like India, was disparately allocated under the caste system. Initially the Kshatriyas were the owners and protectors of the land and, thus, they owned most of the land. Any land owned by others was a result of gifts from the Kshatriya rulers to others in recognition of their service or contribution to the state. However, Indian state governments have used land reforms to try to minimize inequalities in land allocation (Deshpande, 2001). Land reforms have shifted ownership of land to "middle" castes, namely former 'share-croppers' (Desai \& Dubey, 2012). Despite the land 
reforms, the land ownership by "lower" castes is miniscule and negligible. For example, in Uttar Pradesh, an overwhelming majority (over 90\%) of the Scheduled Castes fell into the category that owned 'less than five acres of land'. In many other states too, Dalits were nearly absent among the category that owned 'above five acres' of land (Deshpande, 2001) ${ }^{10}$.

The caste system has not only endowed the "upper" castes with tangible resources such as land and capital, but has also endowed them with intangible resources such as knowledge and status. As economies have modernized, intangible resources have become vital for economic activity (Munshi, 2017). The Brahmins were responsible for the imparting and preservation of knowledge, which formed the basis for the establishment of institutions that exist in Indian society. Through generations of inheritance, Brahmins remained the owners and custodians of ancient knowledge encoded in various scriptures, as well as cultural knowledge, such as arts, dance, and music. Other types of knowledge related to warfare and trading remained with Kshatriyas and Vaisyas, respectively. Any knowledge with respect to other economic activities remained within the boundaries of Sudras.

The caste system greatly affected an individual's status, with those from the "upper" castes possessing high status, and lower status being given to others irrespective of their knowledge and skill levels. For instance, Sudras developed and possessed skills in technology and production; nevertheless, even as complex as these roles are, their birth status as Sudras reduced the prestige of these roles (Saha, 1993). Modernization has further diminished the status of Sudras as technology and mass-production have made their skills redundant, which resulted in them resorting to physical labor to survive (Bayly, 1999). The Dalits or untouchables are

\footnotetext{
10 Our own examination of the data from Socio Econimic and Caste Census 2011 (secc.gov.in) revealed that $4.25 \%$ of the total households in India fell under the category that owned ' 2.5 acres or more irrigated land with at least one irrigation equipment' whereas only $1.28 \%$ of the Dalit households fell into that category.
} 
perceived as being born without skill, wealth, or status. They are perceived as pollutants to the caste system and confined to the fringes of the community (Saha, 1993). The lack of resources limited the economic lives of Dalits, and has left them to scavenge and take up menial jobs (Desai \& Dubey, 2012; Saha, 1993).

In sum, the caste system provided resources to individuals based on their caste. These resources included tangible resources such as wealth and land, and intangible resources such as knowledge and status.

\section{Differential Access to Resources and Opportunities}

The differences in endowments of wealth, land, knowledge, and status meant that those with higher resources are able to have better access to resources and productive opportunities. For example, individuals with resources are able to consume nutritious food, live in a sheltered house, and clothe themselves adequately. As a result, their physical and cognitive development is far better, while the development of those without resources suffers (Elmes, 2018). Similarly, those with resources have better access to healthcare than those without resources. Research evidence shows that such differential access can have a lasting effect on the development of individuals. For example, children's development and well-being is threatened by parents living in poverty and in impoverished environments, resulting in deprivations in nourishment, simple child-care and social interactions (Feldman \& Walton-Allen, 1997). Those children who live in poverty are seen to be 1.3 times more likely to experience learning disabilities and lagged development as compared to nonpoor children (Brooks-Gunn \& Duncan, 1997). Health is also a path through which poverty affects child outcomes, like cognitive ability. Low birth weight and increased blood lead levels in poor children have been associated with decreased measures of cognitive functioning, learning disabilities, dropping out of school and so forth (Brooks-Gunn \& 
Duncan, 1997). In short, deprivation of resources results in low cognitive development, shortterm focused behavior, stress and anxiety, skewed priorities - all of which affect decisionmaking and performance (Bapuji, 2015; Bapuji \& Mishra, 2015).

The caste system has restricted access to education, which is one of the most important means to acquire skills and resources to participate in an economic system. Specifically, individuals could only access the education that helped them to perform the functions they were ordained to. As a result, Brahmins had access to education that helped them to learn scriptures, rules, and rituals, while Kshatriyas learnt the art of warfare and public administration. Others pursued education that helped them to acquire skills necessary for their occupations. However, Dalits were prevented from attending schools and acquiring education. These differences can be found even now, manifested in the high illiteracy rates within Dalits compared to "upper" castes. Lack of education, in turn, leads to poverty. For example, education of individuals explained around $21 \%$ of the poverty incidence gap between scheduled castes and "upper" castes (Gang et.al, 2008).

Access to loans is also reflective of the restrictions placed on "lower" castes. Cooperative banks and financial institutions were usually accessed by the "upper" castes, whereas Dalits depended on private moneylenders, and thus, were burdened by higher interest rates (Hoff, 2016). A recent initiative of the Indian government mandated each of the 134,000 branches of banks, both state-owned and privately-owned, to provide at least two loans to set up a new venture: one to a youth who is a Dalit or an Adivasi, and another to a woman of any caste. Reports indicated that 17 months after the initiative was announced, less than 6 percent of the banks provided loans to Dalits and Adivasis, while about 25 percent provided loans to women. In 
terms of number of loans, the banks provided 33,321 loans to women, but only 7,613 loans to Dalits and Adivasis (Yadav, 2017).

Ritual status within the caste system was reinforced by the foods one consumed and avoided (Stevenson, 1954). To maintain ritual status within the caste, certain foods were avoided and regimens of cooking were followed, including maintaining distance from those who polluted the food. Despite modernization, it is common for the "upper" castes to follow these rituals. For instance, Brahmins follow the satvik diet, which promotes the eating of natural foods that are believed to instill peace and tranquility. This diet provides access to modern ideologies of veganism and lifestyles of the rich, including the adoption of yoga and meditation. In contrast, the "lower" castes, who consumed meat and proscribed spices, did not have access to the same lifestyle, and thus the status associated with it (Stevenson, 1954).

The effect of lower resource endowment on access to resources is most evident in the case of Dalits. They rarely gain access to resources such as formal education, health care, water and sanitation that are needed to ensure their welfare and enhance their opportunities (Sundaram, Sivakumar \& Xavier, 2013). A Dalit's access to natural resources is limited by not owning any land and not having property rights. Dalits can only take water from Dalit wells that are miles from the village and far away from "upper" caste residences; they are restricted from village wells because they are perceived to pollute waterbodies, thereby affecting the ritual status of the “upper" castes (Mair et.al, 2016). Further, they are not allowed to worship in the temples of the village, even when they were expected to build those temples and maintain their cleanliness (Murphy, 2008).

Dalits are constantly faced with the realities of marginalization and degradation. They lack adequate support from political, legislative, economic, and social institutions. And, they are denied 
dignity, rights, and livelihood, resulting in their isolation and alienation from the larger socioeconomic life of the society (Ojha, 2017). Dalits lack access to legislative systems and justice (Babar, 2016). Very few cases of violence and crimes against Dalits result in convictions, as law enforcement agencies lack commitment and are often biased (Jesudasan, 2017). According to the National Commission for Scheduled Castes, crimes against Dalits in Indian states like Uttar Pradesh, Rajasthan, and Bihar have seen an increase from 2013 to 2015 (Pathak \& Sampath, 2016). For instance, $52 \%$ - $65 \%$ of crimes that occurred in Rajasthan were against Dalits. In Uttar Pradesh, crimes against Dalits have increased from 6,201 to 8,066, which is surprising given this state has the highest population of Dalits that would have deterred the perpetrators (Pathak \& Sampath, 2016). Crimes against Dalits normally go unreported due to lack of confidence in authorities, the shame associated with reporting the crime, and threat to their socioeconomic activities (Sharma, 2015). "Upper" caste perpetrators are especially empowered, as failures in reporting crimes and lack of pressure from authorities contribute to the lack of trust in legal systems by the "lower" castes. This also perpetuates the notion of 'secondary victimization', where the broader community from the oppressed caste experiences defenselessness and angst due to recurrent crimes against them (Sharma, 2015).

To improve the access of Dalits to education and skills, the government has created a system of reservations that would help them live a "life of dignity in a democratic society" (Gupta, 2005, p.423). However, the deeply-entrenched caste system means that only a marginal few have access to these resources. More importantly, even when these resources were accessed, the "lower" castes faced many forms of discrimination. For example, even when a political position in a village administration was reserved for a disadvantaged person, the "upper" caste leaders wielded de-facto power and reduced the individual to a symbolic figure (Mair et. al, 
2016). When "lower" castes reached educational institutions, other students and authorities subjected them to direct and indirect discrimination, aimed at undermining their capabilities as well as at isolating them (Thorat, Shyamprasad \& Srivastava, 2007). These acts were partly a result of the resentment that "upper" castes have against reservations, which they argue compromise merit. The words of a Dalit student shine light on the impact of such actions: "it takes so much mental labour to deal with taunt of being 'non-meritorious' and to convince yourself that you deserve to be here and you have to study hard for those among us who still don't have the 'privilege' to enter these institutions. These experiences are agonizing" (Tabhane, 2017).

In sum, the caste system determined access to resources in two ways: first, the endowment of resources based on caste resulted in "upper" castes gaining a better access to certain resources, such as education, health, and nutrition. Second, the hierarchy and prejudice inherent in the caste system enabled better access to "upper" castes, and hindered the access of "lower" castes to dignity, educational and financial institutions, and to systems of justice and governance.

\section{Unequal Reward Systems}

The caste system underpins the system of economic activity and determines an individual's occupation and, thus, income they receive from pursuing those occupations (Desai \& Dubey, 2012). The Brahmins who occupied positions of scholarship received earnings through offerings given by devotees in temples, revenues from temple lands, and offerings for conducting ceremonies and rituals outside the temple. In an urbanized India, priests continue to contextualize and reinterpret Hindu ritual traditions to suit the lifestyles of devotees, thus maintaining their streams of income (Srinivas, 2006). Although large portions of land were 
granted to Brahmins by kings and rulers as a reward for their services, other Kshatriyas often managed those lands (Bendix, 1960). As owners and administrators of land, Kshatriyas earned income through taxation and land rentals. The role of the Vaisyas was to proliferate the prosperity of society through economic exchanges (Pruthi, 2004). As a result, they made up most of trading communities in the Hindu social system and earned their income through commissions and profit margins. The availability of money also granted them roles as money lenders.

Sudras who worked as farmers, artisans, and craftsmen were dependent on "upper-caste" payments to earn their livelihood. Their skills were more physical, and hence their labour was less valued compared to the labour of the "upper" castes, whose skills were more sociocognitive. Therefore, Sudras received less remuneration. Finally, Dalits were left to work in the fields or take up jobs as cleaners. Their earnings were minimal and their labor was often exploited by the upper-castes who denied them wages or made underpayments. For example, it was common for "lower" caste families to be forced to allocate a young family member to provide free labor to the "upper" caste landlords in many villages. Even when "lower" castes received wages for their work, those rewards were not always in the form of wages, but often took the shape of leftover food and grains. Thus, the material inequality of the caste system was visible through the connections between occupation and income (Desai \& Dubey, 2012).

While "lower" castes received fewer financial rewards for their labor, they received minimal non-financial rewards in the form of status, recognition, and progression. For example, no amount of education and learning could make a "lower" caste person a priest - a higher status occupation ${ }^{11}$. Furthermore, the jobs performed by "lower" castes did not give them recognition. As they were deemed unclean, individuals performing those jobs were not appreciated. For

\footnotetext{
11 In a rare exception, one temple has recently appointed a few Dalits and other "lower" castes as priests (Philip, 2017).
} 
example, Dalits performed a number of leather-related activities that involve a high level of skill, such as skinning the animal, curing the hide, and making objects with the leather. In addition, they performed at ceremonies and served social functions, such as carrying messages and making announcements. But, they were still deemed subhuman and their occupations were considered unclean (Ilaiah, 2009).

The vicious cycle of caste and economic inequalities was reinforced through the financial and non-financial rewards retained by the individual castes. Even in modern times, individuals still adopt and are confined to the caste occupations of their forefathers. For example, organizational positions like janitors and sweepers, which pay the lowest of wages, were predominantly given to Dalits (Desai \& Dubey, 2012; Murphy, 2008; 2010). Murphy offers a critique of these practices by discussing the case of Eureka Forbes, which hired 200 men, mostly Dalits, to clean human excrement on railway tracks (Murphy, 2008). Moreover, many Dalits died each year in India because they were sent into septic tanks to clean them, without any protective gear. A recent statistic showed that 51 sanitation workers died in 91 days due to exposure to noxious gases (Nigam \& Dubey, 2017). Such deaths of earning family members, and often the heads of the family in a patriarchal setup, threatened the livelihoods of the entire family. The limited earnings and rewards the Dalits and other "low" castes received were insufficient to save and accumulate resources for further economic development. This perpetuated the inequalities that exist between the rewards that are retained and how they are distributed back into productive resources.

The discrimination faced by Dalits and Adivasis in labour markets has also been found in the businesses run by them. For example, Deshpande and Sharma (2016) found that Dalit and Adivasi-owned businesses were small, owner-operated and survivalist, whereas the businesses 
run by other castes were large, urban and had a fixed workplace. Accordingly, their incomes were higher than those of the Dalit and Adivasi businesses. More importantly, they found evidence that "at least 20 percent of the net income gap could be attributed to the unexplained or the discriminatory component" - much like the sticky floor phenomenon observed with gender gaps (Deshpande \& Sharma, 2016:326). Other studies (e.g., Borooah, 2005; Madheswaran \& Attewell, 2007) too have found a similar income gap for Dalits and Adivasis.

It must be noted that the modern system of economic activity and globalization has changed the economic lives of Dalits, but not always for the better. The footwear cluster in Agra, a city in Northern India, offers a striking example. Traders from the "upper" castes, who owned factories and controlled the marketing channels, dominated the cluster. Dalits, who either worked in the factories or in their homes, made the footwear. The caste relationships and the subsequent lack of economic power resulted in Dalits receiving lesser wages for their labour. Since the liberalization of India, some traders moved up the value chain by automating shoemaking and gained access to profitable foreign markets and premium domestic markets. Other traders faced increasing standards and higher costs, which resulted in many closing down their factories. Consequently, the labour force increased, which exacerbated with the influx of rural migrants. These developments put pressure on smalltime shoemakers, who then turned into shoe workers. On the other hand, wages of shoe workers fell. Consequently, while the value of economic activity in the cluster and the margins of "upper" caste factory owners increased, the incomes of Dalit shoemakers remained stagnant or witnessed a decline (Knorringa, 1999). Not surprisingly, a comprehensive study of the intergenerational occupation mobility between 1983 and 2012 - a period of high economic growth in India, has found that occupational mobilitiy 
decreased for all people, but those decreases were much sharper for Dalits and Adivasis (Reddy, 2015).

Overall, the caste system placed individuals in a hierarchy and endowed people with different levels of financial and non-financial resources. This dispersion in resource endowment resulted in differential access to education and social resources for people of different castes, thus restricting them to only the knowledge and skills needed to perform the roles traditionally assigned to them. The occupational roles in turn determined the level of financial and nonfinancial rewards received, such that the "upper" castes received a lion's share of the wealth generated through economic activity in the society. This enabled the "upper" castes to further accumulate resources and gain access to additional resources, thus reinforcing economic inequalities in society.

\section{THE CASTE LENS ON ECONOMIC INEQUALITY}

Previous conceptualizations and definitions of economic inequality have touched upon the need to focus on non-demographic inequalities, alluded to the role of non-financial resources in inequality, and acknowledged the importance of examining the dispersions in resources, rewards, and opportunities (Bapuji, 2015; Bapuji \& Mishra, 2015; Haack \& Sieweke, 2018; Mair, Wolf and Seelos, 2016; Neckerman \& Torche, 2007; Sen, 1997). Building on these, our examination of the caste system has highlighted (i) the differential endowment of various types of financial and non-financial resources among individuals, (ii) the varying access they had to productive resources and opportunities, (iii) the differential financial and non-financial rewards to productive resources they contributed, (iv) the effect of differential endowments on access and rewards, and (v) the accumulation of such rewards into future endowments. We use these insights to better understand the construct of economic inequality and its existence in contexts 
not necessarily characterized by a caste hierarchy. We present our understanding in Figure 1 and explain it below in more general terms.

Please insert Figure 1 about here

\section{Elements of Economic Inequality and Their Interrelationships}

The caste lens has enabled us to identify various types of resources useful for economic activity, such as wealth, status, and knowledge. Previous research has predominantly focused on economic resources, but it is reductionistic to explain the structures and functions of the social world using only economic aspects because resource endowments useful for economic activity can take the shape of economic capital, social capital or cultural capital (Bourdieu, 1986). Economic capital, or the control over economic resources, can be liquidated and institutionalized through property, assets and money. Cultural capital is the knowledge and intellectual skills that are useful to individuals for achieving higher social status in society. Social capital is the acknowledgement received through networks of institutionalized affiliations that are subject to the resources an individual possesses (Bourdieu, 1986).

Divisions in class are produced by configurations of varying magnitudes of cultural, social, and economic capital. "Symbolic goods" are representative of superiority and merit, thus reinforcing stratagems of "distinction" in society (Bourdieu, 1984). These characteristics intrinsic to cultural capital are shaped by dominant classes and fortify the divisions in class. However, it is important to note that cultural capital is often determined by an individual's social source and not by one's experience or accrued capital. This is reinforced by the assimilation of cultural 
dispositions often inculcated by "definitions that their elders offer them" or their familial or social origins (Bourdieu, 1984:477).

The caste context made it easier to see the operation of various types of resources, but individuals differentially receiving resource endowments is common to all contexts. For example, although regulations determine the extent to which resources can be carried intergenerationally, it is certain that individuals inherit some wealth and capital assets from their families (e.g., house and land). Further, families provide to individuals other assets that can have financial value (e.g., artifacts and heirlooms), even if they are not expressed in financial terms. Additionally, individuals also gain knowledge that resides within their family about socioeconomic life in society, and how to navigate it. More importantly, family membership grants social status to individuals, which not only helps them to command respect, but also builds confidence and esteem. Together these tangible and intangible assets, and financial and non-financial assets, accord privilege to some and serve as handicap to others, which in turn determines these individuals' access to productive resources and opportunities.

Uneven dispersion of resource endowments is a double manifestation of economic inequality, both in terms of its existence and its multiplier effect, i.e., such resource endowment continually amplifies the advantageous position of the owners of these endowments relative to those who lack those tangible and intangible resources. In other words, one element of economic inequality is the extent to which productive resources, particularly those that are extrinsic to an individual, are unevenly endowed in populations. But, another aspect is how such dispersion of extrinsic resources influences the access to resources and productive opportunities.

While the caste system tangibly directs and controls access to productive resources and opportunities, in other contexts, individuals in families with adequate wealth and capital assets 
gain higher access to resources that are needed for their emotional, intellectual, and physical development (Elmes, 2018). Further, individuals from resource-rich families gain better access to education (through private schools or additional academic support) and healthcare. Also, family resources help individuals get better access to technology (e.g., internet, electronic devices, technological devices), which is necessary to create and/or make use of productive opportunities. Further, individuals from asset-rich families can secure financial resources that are difficult for asset-poor families to access, such as bank loans (guaranteed by family assets) and soft loans (from family members). These possibilities are best captured in the idea that each of the three capitals - economic, social, and cultural - can be transformed into other capitals such that those who have economic capital can gain cultural and social capitals, and vice versa (Bourdieu, 1986).

In addition to providing better access to productive resources, resource endowments also influence access to productive opportunities. For example, individuals from asset-rich families can have easy access to advice, information, guidance, and referrals from family members or friends who are likely to be placed high in the socioeconomic hierarchy (Uzzi \& Lancaster, 2003). As a result, they can create or make use of available productive opportunities better than those who are from asset-poor families. For example, those from asset-rich families can engage in opportunity entrepreneurship, which is aimed at building large corporations and generating returns from capital. Those from asset-poor families, on the other hand, engage in necessity entrepreneurship aimed at sustenance, and build small and medium scale enterprises (Lippmann, Davis \& Aldrich, 2005). This is particularly so when dispersion in resource endowments is very high (Xavier-Oliveira, Laplume \& Pathak, 2015). A similar dynamic is also likely present in seeking employment opportunities. Those from asset-rich families are likely to have access to 
professional and specialist jobs by virtue of having the resources needed to invest in relevant education, and having the necessary social networks to receive information and advice. Conversely, those from poor families are more likely to be limited to working-class jobs. Not only that, it is possible that disadvantaged individuals might self-reject themselves and not pursue some opportunities due to the prevalent prejudice and discrimination (Neville, Forrester, O’Toole \& Riding, 2017). In short, those from asset-rich families can access a range of productive resources and productive opportunities in the environment, whereas those from assetpoor families struggle to access them or may access them only at higher costs.

The differential access that the rich and the rest have to productive resources and opportunities affects the level of rewards they can receive for their inputs to value creation in organizations (Bapuji et al., 2018). Those engaging in opportunity entrepreneurship receive higher returns for their inputs than those pursuing necessity or subsistence entrepreneurship (Lippman et al., 2005). The shareholder-focused management of corporations results in top executives and shareholders (who are more likely to be from asset-rich families) receiving a much higher share of wealth created in organizations; whereas employees, suppliers, and buyers receive very little (Bapuji et al., 2018; Sjoberg, 2009). Under a shareholder-value regime, downsizing, layoffs, and reduction in compensation and benefits for employees occur routinely (Lazonick \& O’Sullivan, 2000; Cobb \& Lin, 2017), whereas shareholders receive higher returns in the form of dividends, stock repurchases and cash holding. Also, top executives receive higher compensation - both monetary and non-monetary - to align their interests with those of the shareholders (Lazonick \& O’Sullivan, 2000).

The distribution of non-financial rewards follows the same path as the financial rewards received by the dominant groups. Those holding professional and premium jobs have higher 
chances of mobility and are likely to receive recognition for their contributions. In addition, they are also likely to have better job security and have insurance against likely losses (e.g., golden parachutes). However, those in ordinary jobs are likely to have fewer opportunities for mobility, security and recognition. And, even when those are present and achieved, the payoff is lower compared to the payoff for premium positions.

The uneven distribution of wealth created in corporations enables shareholders and executives to accumulate and enhance their resource endowments. The limited share of rewards received by employees, contractors and others leaves them with little to add to, to accumulate their resource endowments. Consequently, the resources of the privileged help them gain access to better resources and opportunities and command a premium for their inputs; whereas, the poor are unable to do so. As a result, economic inequalities are exacerbated and reinforced ${ }^{12}$.

In sum, we have argued that the three elements of economic inequality - resource endowments, access to productive resources and opportunities, and rewards to resources - are interrelated. High levels of resource endowments enable individuals to access a higher range of resources and productive opportunities, which in turn provide them with greater returns. Those returns, in turn, help them to further enhance their resources endowments. This interrelationship, by which resource endowments determines access to productive resources and opportunities, also determines the level of rewards, thus perpetuating economic inequality.

\section{DISCUSSION}

\footnotetext{
12 In explaining the interlinkages between the various elements of economic inequality, we excluded the processes of value creation and distribution within firms and other economic entities, which influence dispersion in rewards. This is because our interest is primarily to contribute to the theorization of the broader construct of economic inequality rather than focus only on income inequality. Also, other scholars (e.g., Bapuji, 2015; Bapuji et al., 2018; Cobb, 2016; Cobb \& Stevens, 2016; Cobb \& Lin, 2017) have examined the processes within firms that contribute to uneven dispersion of rewards, and the consequent income inequality.
} 
Organizational researchers have recently turned their attention to economic inequality because organizations are at the center of wealth creation and distribution. This research has begun to examine the role of organizational strategies and practices in creating income inequality at the societal level (Bapuji et al., 2018; Cobb, 2016), and how income inequality shapes the institutional environment for business (Bapuji \& Neville, 2015; Beal and Astakhova, 2017; Beal et al., 2017). Scholars have argued that studying institutions that shape individual and organizational action can yield important insights about economic inequality (Amis et al., 2017; Davis, 2017). Further, previous research has limited its attention to economic dimensions such as income and wealth and has not developed the construct of economic inequality. To address these two issues, we studied the caste system as an institution to understand how it influences socioeconomic inequalities. This examination has, in turn, helped us to elaborate on the construct of economic inequality. Accordingly, this paper contributes to the study of economic inequality as well as the caste system, and opens up avenues for future inquiry by organizational scholars. We elaborate on this in the following sections.

\section{Contributions to Economic Inequality Research and Future Research Opportunities}

Our paper makes two important contributions to organizational research on economic inequality. First, it enriches the construct of economic inequality. Second, it studies caste as an institution of inequality and advances an institutional approach to the study of economic inequality.

\section{Enriching the Construct of Economic Inequality}

In this paper, we argued that resource endowments, access to productive resources and opportunities, and rewards to resource contribution are interlinked, which makes it possible for the perpetuation of economic inequalities in a society. In other words, resource endowments 
determine access to resources, which together determine the rewards received for the resource contributions made by individuals. This conceptualization builds on a previous definition of economic inequality: "uneven dispersion in resource endowments, access to productive resources, and rewards for labour in a social collective that limits the fulfilment of human functions" (Bapuji, 2015:1061).

In addition to identifying the interrelationships between resource endowments, resource access and rewards to labor, we have elaborated on the three elements of economic inequality: First, we highlighted that resource endowments consist of both financial and non-financial resources, which should be considered to better capture economic inequality and, more importantly, to better understand how various types of non-financial resources contribute to the creation and maintenance of economic inequality. One of the primary sources of inequality is uneven resource endowments or inheritance of wealth by individuals. However, the contribution of inherited wealth to overall inequality has been decreasing because many contries in the developed world have attempted to diminish and/or discourage wealth accumulation through inheritance. Not surprisingly, Piketty \& Saez (2003) found that the working rich have replaced the rentiers at the top of the income distribution in the US, reflecting decreasing returns to capital and increasing returns to executive skills. Although there is recent evidence to indicate that intergenerational mobility has decreased, the sources of such immobility are rooted in the complex ways in which income and wealth inequalities affect the socioeconomic lives of individuals, rather than the inheritance of wealth alone (Wilkinson \& Pickett, 2009). This points to the possibility that endowment of non-financial resources, such as status, social capital and knowledge, are likely to affect overall economic inequality more than wealth inequality. 
Therefore, it is important for future researchers to examine the role of social capital and cultural capital alongside economic capital in creating and maintaining economic inequality.

Second, we underscored the importance of productive opportunities available to individuals to improve their position. This goes beyond previous conceptualizations that included access to resources as an element of economic inequality, and suggests that the sources of inequality are not just in the differential access to resources; inequality is also influenced by differential access of individuals to productive opportunities. This access to opportunities is what makes it difficult for individuals from disadvantaged backgrounds to improve their economic conditions, while those from privileged backgrounds maintain and improve their economic conditions. If individuals at the lower end of the economic pyramid can access resources in the same manner as those at the top of the economic pyramid, then inequality is unlikely to perpetuate itself (Elmes, 2018). Therefore, it is useful to theorize and empirically examine the independent effect of access to resources and productive opportunities on economic inequality. Depending on the relative importance of access to resources or opportunities, policy and organizational interventions vary. For example, governments can provide access to loans through banks, but if the disadvantaged are unable to access that opportunity due to discrimination, more interventions such as sensitivity training or closer monitoring will become necessary to realize the objectives of such loans.

Third, our examination of caste system helped us to illuminate the 'rewards to labour' element of economic inequality. It has shown that while financial rewards to labour are important to understand economic inequality, non-financial rewards such as status, recognition, and progression are also important aspects. Further, a focus only on labour, which is just one input into the production process, ignores the contribution of non-labour resources - such as 
knowledge, social capital, and financial capital - to the creation of value. This is in line with Bapuji et al., (2018) who identified various types of contributors (e.g., employees, executives, shareholders, government, and the society at large) and their contribution of financial and nonfinancial resources to value creation in organizations. Specifically, by extending from 'rewards to labour' to 'rewards to productive resources,' we can more comprehensively consider the resource contributions of various stakeholders to value creation and the returns they receive in turn, in the form of compensation, dividends, taxation, and philanthropy - all of which contribute to economic inequality at the societal level.

A richer understanding of the construct of economic inequality is necessary because previous research on economic inequality, mainly conducted in non-business disciplines, has equated economic inequality with income and wealth inequalities. Further, research in nonbusiness disciplines has shown empirical relationships, but theoretical explanations for those relationships have been fewer. One of the strengths that organizational scholars can bring to inequality research is the theorization of mechanisms that drive the canonical relationships found in empirical studies in economics and epidemiology that have shown a negative effect of economic inequality on economic growth and population health.

Overall, our paper elaborated on the construct of economic inequality to emphasize the role of non-financial resources, access to productive opportunities, and returns to all resource contributors, as well as highlighted the relationship between the three elements of economic inequality: endowments, access, and rewards. By enriching the construct of economic inequality and theorizing the relationships between various dimensions of economic inequality, organizational researchers can inform other areas of scholarly inquiry such as economics, sociology and epidemiology. 


\section{Institutional Approach to the Study of Economic Inequality}

In this paper, we have examined the caste system to identify its features and used it as a lens to shed some light on the construct of economic inequality. In doing so, we have responded to the calls for an institutional approach to study socio-economic inequalities (Amis et al., 2017; Davis, 2017; Suddaby et al., 2018). The caste system is a unique institution that can be found predominantly in the Indian subcontinent. Recent studies indicate that the emigration of Indians to other countries has resulted in them carrying some aspects of the caste system to their host countries such as US and UK (Gidla, 2017; Metcalf \& Rolfe, 2010; Zwick-Maitreyi et al., 2018). Although the caste system has been abolished by law and various reformers have tried to change it, the caste system thrives as an institution. As such, it provides an example of a strong institution that has retained its potency largely through normative and cognitive dimensions. Therefore, studying the caste system can generate much needed insights about the persistence of institutions, particularly oppressive institutions.

Organizational researchers can also unearth fresh insights by studying how the caste system perpetuates socioeconomic inequalities. The caste system is a unique form of barrier to social mobility, but such insidious barriers exists in all societies, and the insights from caste can be extrapolated to inform those studies, as well. In this paper, we have argued that the caste system preserves socioeconomic inequalities by influencing resource endowments, access, and rewards. While this is an economic explanation predominantly based on value creation and distribution, the caste system maintains socioeconomic inequalities through everyday practices and habits, such as last names, food habits, clothing styles, ceremonies, rituals and relationships. It will be instructive to understand how such everyday actions perpetuate caste as an institution of inequality (Amis et al., 2017). 
It is also important to understand the play of institutional logics in the maintenance of caste system. Institutional logics mold rational and cognizant behavior of individual and organizational actors who, in turn, play a critical role in molding and altering these logics (Thornton, 2004). A central logic exists in every institutional order and directs and manages organizing principles and equips social entities with directives of purpose and identity (Friedland \& Alford, 1991). It appears that the caste system is legitimized through religious logics, de-legitimized using the logic of equality, and re-legitimized through the economic logic of merit. Specifically, the caste system was explained and justified as a divine invention based on the philosophy of karma, i.e., you reap what you have sowed in previous births. It was further justified through the concept of reincarnation, i.e., you can get a better birth in the next life by doing good in this birth. This has been contested by various reformers and "lower" castes using the logic of equality, e.g. Gandhi's characterization of untouchables as children of god, like the rest. In recent times, however, the caste system is being re-legitimized using economic logic, i.e., people were allocated to occupations based on their skills, which then became their caste. While our characterization of these logics is coarse, it is not meant to be an explanation of the legitimation strategies; Rather, it is meant to spur thinking about the various strategies and logics used by individuals and groups to understand caste and its role in social and economic life in the Indian subcontinent and elsewhere. An examination of the various logics that maintain and resist caste system can provide new insights to the research on institutional logics (Thornton \& Ocasio, 2008; Reay \& Hinings, 2009; Thornton, Ocasio \& Lounsbury, 2012).

Examining economic inequality through a caste lens involves scrutinizing the play of various institutional dynamics, which have often been explicated through the use of institutional logics. But, institutional logics may not be sufficient to understand the dynamics of a caste 
system as logics often construct shared meaning, as they are affixed to networks of actors founded on power and governance structurations, legitimized by practices and identities and are often conceptualized as competing (Reay \& Hinings, 2009; Hinings, Logue \& Zietsma, 2017). These shared institutional logics confine and delineate the boundaries and identities within which "clusters" of organizations exist, otherwise known as organizational fields (Greenwood \& Suddaby, 2006). Focus on institutional logics has primarily brought to the forefront the construction of meaning (Thornton, Ocasio \& Lounsbury, 2012; Hinings et al., 2017). However, fields or "common meaning systems" cannot rely only on logics, but need to examine the structural elements that form the backbone of field activity (Hinings et al., 2017). While in economics institutional infrastructure elements have been assayed in tandem with income inequality, the discipline has mainly directed its attention to corruption, economic growth and bureaucracy (Hinings et.al, 2017). An institutional infrastructure is forged by formal and informal elements like regulators, status differentiators, norms, relational channels or netrworks and labels. These provide the tools needed to understand organizations within fields and how these fields are structured based on connections and institutional activities amidst actors (Dacin, Ventresca \& Beal, 1999; Hinings et.al, 2017). These actors or structures accommodate roles of governing, judgment, and management of other actors in a cluster. Through this structuration, status is shaped, and behavior of members is dictated or steered due to the emergence of shared and enacted interests and values (Hinings et al, 2017). Therefore, future studies on the perpetuation of economic inequality can examine the institutional infrastructure of the caste system to understand the structures of governance and power that exist in a field and how the resultant interests and values influence the behaviors of members. 
Overall, our paper adopted an institutional approach to examine the construct of economic inequality by using the caste lens. As a unique institution that creates and maintains socioeconomic inequalities, the caste system itself needs to be examined by comprehending its features, the institutional logics that support it, and the institutional infrastructures that perpetuate it. Such examination, we believe, would generate fresh insights about institutional theory, particularly about institutional logics and institutional infrastructures.

\section{Contribution to Caste Research in Organizations and Future Research Opportunities}

Although the caste system affects the socioeconomic lives of more than a billion people, organizational scholarship has paid surprisingly little attention to it. The most common references to caste relate to its hierarchy, class nature, and discrimination (e.g., Primeaux \& Beckley, 1999; Van Luijk, 1997). Occasionally, caste has been used as a demographic characteristic to study populations (e.g., Suar \& Gochhayat, 2016). In some cases, the caste formed the backdrop to study class relations in collaborations (e.g., Dar, 2018) or examine frugal consumption (Jagannathan, Bawa \& Rai, forthcoming). Very few organizational scholars have incorporated caste into their studies in a significant manner. For example, Vissa (2011) has examined how caste helps the formation of network ties between entrepreneurs in India. Further, Chen, Chittoor, and Vissa (2015) found that analyst forecasts are more accurate when analysts and CEOs share the same caste. In another interesting study, it was found that caste identities that foster inequalities have also affected the interactions within trade unions, whose aim is to foster equality and work for the disadvantaged (Pandey \& Varkkey, forthcoming).

In contrast to research in other disciplines that has focused more on economic inequality - even if it was limited to dispersion in wealth and income, organizational research and practice has paid greater attention to demographic inequality, i.e., disparities in experiences or outcomes 
that have a basis in demographic characteristics (e.g., gender, race, and age) (Bapuji \& Mishra, 2015). However, this research has not paid attention to inequalities that have roots in caste, which is often used as a demographic characteristic by researchers who used data from India (e.g., Sarkar, Roufin \& Haughton, 2018). Focusing on the caste system and its implications to inequality can inform research on demographic inequality. This, in turn, can spur research on how organizations can be made more inclusive, not just for those disadvantaged due to gender, race, ethinicity, age and sexual orientation, but also those oppressed due to caste.

Using the caste lens to examine organizational theory and practice implies that the features and characteristics of the caste system be identified and comprehended. In this paper, we have identified a few important features of the caste system: hierarchy, assignment of occupations, restricted upward mobility, and constrained socioeconomic interactions. While these are a few prominent features, a number of other features exist that are too expansive to be covered in a single article, particularly given the thousands of castes and sub-castes in India. A comprehensive study of those features and their implications to organizations would help management scholars to adopt a caste lens to improve organizational theory and practice.

Although modernization appears to have diminished the importance of caste, evidence also reveals that caste identities are strengthening and becoming important tools for social movements. In recent years, many caste groups have escalated their demand for a share in government educational institutions and in government jobs. For example, various dominant caste groups in India, who are either "upper" castes or have been categorized as forward castes, such as Patels in Guajarat, Jats in Haryana, Marathas in Maharashtra, and Kapus in Andhra Pradesh have recently resorted to violent protests in an attempt to pressurize the state to gain access to higher education and jobs in the public sector. Studying how caste influences 
individual identities that result in collective actions, and how caste identities affect organizations and societies can reveal insights about the effect of institutions on identities (Amis et al., 2017; Srinivas, 2013).

Organizational scholarship and business education is 'weak in acknowledging preexisting social differences, let alone providing solutions for addressing the differential outcome of wealth and opportunity that neoliberalism produces' (Fotaki \& Prasad, 2015:559). By enriching the construct of economic inequality and theorization of its dimensions, and studying the caste system, organizational scholars can shed light on how differences in resource endowments influence access to and rewards for resources. Such scholarship can, in turn, pave way for contesting the rhetoric that aims to justify the existing systems of inequality such as 'caste system is only occupational classification' and 'passing wealth to future generations is one's personal liberty'. Such arguments underplay the complex and nuanced ways in which privilege is maintained and reproduced in societies and organizations. By studying those issues, organizational scholars can develop mechanisms to decrease inequality, for example, how to strengthen affirmative actions (rather than weaken them in the name of merit) and how to shape organizations to be more accommodative to the socioeconomically less privileged, just as they have been accommodative to issues of gender, race, and sexual orientation.

In conclusion, in this paper we have examined the caste system in India and used it as a lens to understand the various elements of economic inequality and the interreleationships between them. Our study of the caste system, as an institution, serves to illustrate the potential of the caste system studies to inform research on institutions, as well as research on economic inequality. We hope that organizational scholars focus on institutions of socioeconomic inequality in society and their effect on individuals and organizations. 


\section{References}

Agrawal, R. (2016). India's Caste System: Outlawed, but still Omnipresent. February 24. Accessed on Nov 29, 2017. http://edition.cnn.com/2016/02/23/asia/india-castesystem/index.html.

Akerlof, G. (1976). The Economics of Caste and of Rat Race and Other Woeful Tales. The Quarterly Journal of Economics, 90(4), 599-617.

Alamgir, F., \& Cairns, G. (2015). Economic inequality of the badli workers of Bangladesh: Contested entitlements and a 'perpetually temporary'life-world. Human Relations, 68(7), 1131-1153.

Amis, J. M., Munir, K. A., \& Mair, J. (2017). Institutions and economic inequality. The SAGE handbook of organizational institutionalism (2nd ed.). Thousand Oaks, CA: Sage.

Andrews, T. G., \& Htun, K. T. (2017). Corruption in Myanmar: Insights from business and education. In The Changing Face of Corruption in the Asia Pacific, 233-242.

Babar, A. V. (2016). Rape as a Continuing Weapon of Psychological Warfare, Suppression \& Subjugation. The International Journal of Indian Psychology, 3(2), 80-97

Banerjee, S. (2003). Gender and nationalism: the masculinization of Hinduism and female political participation in India. In Women's Studies International Forum. 26(2). 167-179.

Bapuji, H. (2015). Individuals, interactions and institutions: How economic inequality affects organizations. Human Relations, 68(7), 1059-1083.

Bapuji, H., Husted, B., Lu, J., \& Mir, R. (2018). Value Creation, Appropriation and Distribution: How Firms Contribute to Societal Economic Inequality. Business and Society, 57 (6): 9831009.

Bapuji, H. \& Mishra, S. Inequality and business. (2015). In Mir, R., Willmott, H., \& Greenwood, M. (Eds.), Companion to Philosophy in Organization Studies. 439-448. Routledge: New York.

Bapuji H, Neville L. (2015). Income Inequality Ignored? An Agenda for Business and Strategic Organization. Strategic Organization, 13(3), 233-246.

Bayly, S. (1999). Caste, Society and Politics in India from the Eighteenth Century to the Modern Age. New Cambridge History of India. Cambridge: Cambridge University Press.

Beal, B. D., \& Astakhova, M. N. (2017). Management and Income Inequality: A Review and Theoretical Model. In Academy of Management Proceedings. Academy of Management. 2015 (1), 14729.

Beal, B. D., Astakhova, M., \& Conaway, R. N. (2017). Income inequality and management theory: Systemic considerations and causal paths. In Academy of Management Proceedings, 2017(1), 12233. Academy of Management.

Bendix, R. (1960). Max Weber: an intellectual portrait (Vol. 2). Psychology Press.

Blumer, H. (1958). Race prejudice as a sense of group position. Pacific Sociological Review, 1(1), 3-7.

Bobo, L. (1998). Race, interests, and beliefs about affirmative action: Unanswered questions and new directions. American Behavioral Scientist, 41(7), 985-1003.

Borooah, V.K. (2005). Caste, inequality, and poverty in India. Review of Development Economics, 9(3), 399-414.

Bourdieu, P. (1984). A social critique of the judgement of taste. Traducido del francés por $R$. Nice. Londres, Routledge. 
Bourdieu, P. (1986). The force of law: Toward a sociology of the juridical field. Hastings LJ, 38, 805.

Brooks-Gunn, J., \& Duncan, G. J. (1997). The effects of poverty on children. The future of children, 55-71.

Chakravarti, U. (2012). Patriarchy BralimaniLcal Conceptualising India Early in Gender , Caste , Class and State. Economic And Political Weekly, 28(14), 579-585.

Chen, G., Chittoor, R. and Vissa, B. (2015). Modernizing without Westernizing: Social structure and economic action in the Indian financial sector. Academy of Management Journal, 58(2), 511-537.

Chirakarode, P. (1993). Ambedkar : Budhika Vikasobhathinte Agnijwala. Dalit Books. Thiruvalla.

Chishti, S. (2014, November 29). Biggest caste survey: One in four Indians admit to practising untouchability. Retrieved December 10, 2017, from http://indianexpress.com/article/india/india-others/one-in-four-indians-admit-to-practisinguntouchability-biggest-caste-survey/

Cobb, J. A. (2016). How Firms Shape Income Inequality: Stakeholder Power, Executive Decision-Making, and the Structuring of Employment Relationships. Academy of Management Review, 41(2), 324-348.

Cobb, J.A. and Lin, K.H. (2017). Growing Apart: The Changing Firm-Size Wage Premium and Its Inequality Consequences. Organization Science. https://doi.org/10.1287/orsc.2017.1125

Cobb, J.A. \& Stevens, F.G. (2016). These Unequal States Corporate Organization and Income Inequality in the United States. Administrative Science Quarterly, $10.1177 / 0001839216673823$.

Cotterill, S., Sidanius, J., Bhardwaj, A., \& Kumar, V. (2014). Ideological support for the Indian caste system: Social dominance orientation, right-wing authoritarianism and karma. Journal of Social and Political Psychology, 2(1), 98-116.

Dacin, M. T., Beal, B. D., \& Ventresca, M. J. (1999). The embeddedness of organizations: Dialogue \& directions. Journal of management, 25(3), 317-356.

Dar, S. (2018). De-Colonizing the Boundary-Object. Organization Studies, 39(4), 565-584..

Davis, G.F. (2017). Organizations, Institutions, and Inequality. The SAGE handbook of organizational institutionalism (2nd ed.). Thousand Oaks, CA: Sage.

Davis, G. F., \& Cobb, J. A. (2010). Corporations and economic inequality around the world: The paradox of hierarchy. Research in Organizational Behavior, 30, 35-53.

Desai, S., \& Dubey, A. (2012). Caste in 21st Century India: Competing Narratives. Economic And Political Weekly, 46(11), 40-49.

Deshpande, A. (2001). Caste at Birth? Redefining Disparity in India. Review of Development Economics 5(1): 130-44.

Deshpande, A. (2013). Social justice through affirmative action in India: an assessment. Capitalism on Trial: Explorations in the Tradition of Thomas E. Weisskopf. Northhampton: Edward Elgar Publishing Limited, 266-285.

Deshpande, M. S. (2010). History of the Indian Caste System and Its Impact on India Today. San Luis Obispo.

Deshpande, A. and Sharma, S. (2016). Disadvantage and discrimination in self-employment: caste gaps in earnings in Indian small businesses. Small Business Economics, 46(2), 325346. 
Dumont, L. (1980). Homo hierarchicus: The caste system and its implications. University of Chicago Press.

Elmes, M. B. (2018). Economic Inequality, Food Insecurity, and the Erosion of Equality of Capabilities in the United States. Business \& Society, 57 (6): 1045-1074.

Feldman, M. A., \& Walton-Allen, N. (2002). Effects of maternal mental retardation and poverty on intellectual, academic, and behavioral status of school-age children. The best of AAMR:

Families and mental retardation: A collection of notable AAMR journal articles across the 20th century, 235-246.

Fotaki, M., \& Prasad, A. (2015). Questioning neoliberal capitalism and economic inequality in business schools. Academy of Management Learning and Education, 14(4), 556-575. doi.org/10.5465/amle.2014.0182.

Friedland, R., \& Alford, R. R. (1991). Bringing society back in: Symbols, practices and institutional contradictions. 232-263.

Gang, I. N., Sen, K., \& Yun, M.-S. (2008). Poverty in Rural India: Caste and Tribe. Review of Income and Wealth, 54(1), 50-70.

Ghurye, G. S. (1932). Caste and Race in India. London: Routledge and Kegan Paul

Giddens, A. (1984). The constitution of society.

Gidla, S. (2017). Ants Among Elephants: An untouchable family and the making of modern India. Farrar, Straus and Giroux: New York.Greenwood, R., Raynard, M., Kodeih, F., Micelotta, E. R., \& Lounsbury, M. (2011). Institutional complexity and organizational responses. Academy of Management annals, 5(1), 317-371.

Greenwood, R., \& Suddaby, R. (2006). Institutional entrepreneurship in mature fields: The big five accounting firms. Academy of Management journal, 49(1), 27-48.

Grey, M. (2005). Dalit Women and the Struggle for Justice in a World of Global Capitalism. Feminist Theology, 14(1), 127-149.

Gupta, D. (2005). Caste and Politics: Identity Over System. Annual Review of Anthropology, 21, 409-427.

Haack, P., \& Sieweke, J. (2018). The Legitimacy of Inequality: Integrating the Perspectives of System Justification and Social Judgment. Journal of Management Studies, 55(3), 486-516.

Hinings, C. R., Logue, D. M., \& Zietsma, C. (2017). Fields, institutional infrastructure and governance. The Sage Handbook of Organizational Institutionalism.

Hoff, K. (2016). Caste System. World Bank Policy Research Working Paper No. 7929

Hyman, R.(2006). Marxist Thought and the analysis of Work. In Korczynski, M., Hodson, R., \& Edwards, P. K. (Eds.). Social theory at work. OUP Oxford.

Ilaiah, K. (2009). Post-Hindu India: A Discourse on Dalit-Bahujan Socio-Spiritual and Scientific Revolution. New Delhi: Sage Publications.

Jagannathan, S., Bawa, A., \& Rai, R. (forthcoming). Narrative Worlds of Frugal Consumers: Unmasking Romanticized Spirituality to Reveal Responsibilization and Depoliticization. Journal of Business Ethics, https://doi.org/10.1007/s10551-018-3931-1.

Jesudasan, D. S. (2017, March 30). T.N.'s conviction rate in SC/ST cases dismal. Retrieved December 1, 2017, from http://www.thehindu.com/news/national/tamil-nadu/tnsconviction-rate-in-scst-cases-dismal/article17746347.ece

Jha, A. (2017, November 24). RTI Reveals IIT Kanpur Fails Students Of Only Certain Castes. Retrieved December 10, 2017, from https:/www.youthkiawaaz.com/2017/11/iit-kanpurexpelled-students-hundred-percent-reserved-category/ 
Jiang, L., \& Probst, T. M. (2017). The rich get richer and the poor get poorer: Country-and statelevel income inequality moderates the job insecurity-burnout relationship. Journal of Applied Psychology, 102(4), 672.

Knorringa, P. (1999). Agra: An old cluster facing the new competition. World Development, 27(9).

Kumar, K. (2017). Indian constitution: The vision of BR Ambedkar. Intellectual Resonance, 144.

Laar, C. V., Levin, S., \& Sinclair, S. (2008). Social identity and personal identity stereotype threat: The case of affirmative action. Basic and Applied Social Psychology, 30(4), 295-310.

Lazonick, W., \& O'Sullivan, M. (2000). Maximizing shareholder value: a new ideology for corporate governance. Economy and society, 29(1), 13-35.

Leach, E. R. (Ed.). (1960). Aspects of caste in south India, Ceylon and North-west Pakistan (No. 2). CUP Archive.

Leana, C. R., \& Meuris, J. (2015). Living to work and working to live: Income as a driver of organizational behavior. Academy of Management Annals, 9(1), 55-95.

Lenski, G. E. (2013). Power and privilege: A theory of social stratification. UNC Press Books.

Lippmann, S., Davis, A., \& Aldrich, H. E. (2005). Entrepreneurship and inequality. In Entrepreneurship (pp. 3-31). Emerald Group Publishing Limited.

Lowery, B. S., Unzueta, M. M., Knowles, E. D., \& Goff, P. A. (2006). Concern for the in-group and opposition to affirmative action. Journal of personality and social psychology, 90(6), 961.

Mair, J., Wolf, M., \& Seelos, C. (2016). Scaffolding: A process of transforming patterns of inequality in small-scale societies. Academy of Management Journal, 59(6), 2021-2044. doi.org/10.5465/amj.2015.0725.

Madheswaran, S. and Attewell, P., 2007. Caste discrimination in the Indian urban labour market: Evidence from the National Sample Survey. Economic and political Weekly, 4146-4153.

Marsh, R. M. (2016). What Have We Learned from Cross-National Research on the Causes of Income Inequality?. Comparative Sociology, 15(1), 7-36.

McCall, L., \& Percheski, C. (2010). Income inequality: New trends and research directions. Annual review of sociology, 36, 329-347.

Metcalf, H., \& Rolfe, H. (2010). Caste discrimination and harassment in Great Britain. National Institute of Economic and Social Research Report (NIESR), 101213.

Mondal, P. (2014, April 14). Differences between Class and Caste Systems. Retrieved December 27, 2017, from http://www.yourarticlelibrary.com/sociology/differences-between-class-andcaste-systems/35101/

Muckenhuber, J., Burkert, N., Großschädl, F., \& Freidl, W. (2014). Income inequality as a moderator of the relationship between psychological job demands and sickness absence, in particular in men: An international comparison of 23 countries. PloS one, 9(2), e86845.

Munshi, K. (2017). Caste and the Indian Economy. University of Cambridge

Murphy, J. (2008). Management in emerging economies: modern but not too modern?. Critical Perspectives on International Business. 4(4). 410-421.

Murphy, J. (2010). A toxic mix? Comparative efficiency and the privatization of sanitation services in India. Public Administration and Development. 30(2). 124-135.

Neckerman, K.M. \& Torche, F. (2007). Inequality: Causes and consequences. Annual Review of Sociology, 33, 335-357. 
Neville, F., Forrester, J. K., O'Toole, J., \& Riding, A. (2018). 'Why Even Bother Trying?'Examining Discouragement among Racial-Minority Entrepreneurs. Journal of Management Studies, 55(3), 424-456.

Nigam, D. \& Dubey, S. (2017, November 24). We Are All Complicit in the Institutional Murders of Dalit Sanitation Workers. Retrieved December 10, 2017, from https://thewire.in/198993/sanitation-workers-deaths-caste-swachh-bharat/

North, D. C. (1990). A transaction cost theory of politics. Journal of theoretical politics. 2(4). 355-367

Ojha, R. (2017). As Women and As Dalit: A Dalit Feminist Perspective. In N. D. Publishers (Ed.). Development and Perspectives: Towards New Challenges. 69-78. New Delhi.

Pandey, J. and Varkkey, B., Forthcoming. Impact of Religion-Based Caste System on the Dynamics of Indian Trade Unions: Evidence from Two State-Owned Organizations in North India. Business \& Society, DOI: https://doi.org/10.1177/0007650317745867.

Pathak, V. \& Sampath, G. (2016, July 24). U.P., Bihar lead in crimes against Dalits. Retrieved December 1, 2017, from http://www.thehindu.com/data/U.P.-Bihar-lead-in-crimes-againstDalits/article14506278.ece

Philip, S. (2017, October 15). Kerala Dalit priests: 'Any Hindu can be a Brahmin'. Retrieved December 10, 2017, from http://indianexpress.com/article/india/kerala-dalit-priestsgovernment-temples-any-hindu-can-be-a-brahmin-4890673/

Piketty, T. (2014). Capital in the Twenty-First Century. Cambridge, MA: Belknap Press.

Piketty, T. and Saez, E. (2003) Income inequality in the United States, 1913-1998. Quarterly Journal of Economics, 118(1), 1-41.

Primeaux, P. and Beckley, J. (1999). Double bookkeeping: hierarchical obedience and participative cooperation. Journal of Business Ethics, 19(1), 123-136.

Pruthi, R. K. (Ed.). (2004). Indian caste system. Discovery Publishing House.

Qureshi, I., Sutter, C., \& Bhatt, B. (2017). The transformative power of knowledge sharing in settings of poverty and social inequality. Organization Studies, 0170840617727777.

Reay, T., \& Hinings, C. R. (2009). Managing the rivalry of competing institutional logics. Organization studies, 30(6), 629-652.

Reddy, A.B. (2015). Changes in intergenerational occupational mobility in India: Evidence from national sample surveys, 1983-2012. World Development, 76, 329-343.

Reinecke, J., Forthcoming. Social Movements and Prefigurative Organizing: Confronting entrenched inequalities in Occupy London. Organization Studies, DOI: 10.1177/0170840618759815.

Saha, A. (1993). International Journal of Sociology and Social Policy Article information : International Journal of Sociology and Social Policy, 13(3/4), 1-76.

Sarkar, S., Rufín, C. and Haughton, J. (2018). Inequality and entrepreneurial thresholds. Journal of Business Venturing, 33:278-295.

Scott, W. R. (1987). The adolescence of institutional theory. Administrative science quarterly. 493-511.

Scott, W. R. (1995). Institutions and organizations. Foundations for organizational science. London: A Sage Publication Series.

Sen, A (1997). On economic inequality. New York, NY: Oxford University Press.

Sharma, S. (2015). Caste-based crimes and economic status: Evidence from India. Journal of comparative economics, 43(1), 204-226. 
Sjoberg, G. (2009). Corporations and human rights. Interpreting Human Rights: Social Science Perspectives, 47, 157.

Srinivas, M. N., Damle, Y. B., Shahani, S., \& Beteille, A. (1959). Caste : A Trend Report and Bibliography. Current Sociology, 8(3), 135-151.

Shrivastava, P., \& Ivanova, O. (2015). Inequality, corporate legitimacy and the Occupy Wall Street movement. Human Relations, 68(7): 1209-1231.

Srinivas, N. (2013). Could a subaltern manage? Identity work and habitus in a colonial workplace. Organization Studies, 34(11), 1655-1674.

Srinivas, T. (2006). Divine enterprise: Hindu priests and ritual change in neighbourhood hindu temples in Bangalore. South Asia: Journal of South Asian Studies, 29(3), 321-343.

Stevenson, H. N. C. (1954). Status evaluation in the Hindu caste system. Journal of the Royal Anthropological Institute of Great Britain and Ireland. 84. 45-65

Strauss, A. L. (2017). The contexts of social mobility: Ideology and theory. Routledge.

Suar, D. \& Gochhayat, J. (2016). Influence of biological sex and gender roles on ethicality. Journal of Business Ethics, 134(2), 199-208.

Suddaby, R., Bruton, G. D., \& Walsh, J. P. (2018). What We Talk About When We Talk About Inequality: An Introduction to the Journal of Management Studies Special Issue. Journal of Management Studies, 55(3), 381-393.

Sundaram, G., Sivakumar, R., \& Xavier, L. (2013). Dalit Rape Victims: An Analysis of Victim Justice in India. In Second International Conference of the South Asian Society of Criminology and Victimology (SASCV)150-153.Tamil Nadu.

Tabhane, T. (2017, December 07). Indian campuses through the eyes of an Ambedkarite student. Retrieved December 10, 2017, from http://indianexpress.com/article/gender/genderandindian-campuses-through-the-eyes-of-an-ambedkarite-student/

Thekaekara, M. M. (2016, August 15). India's caste system is alive and kicking - and maiming and killing | Mari Marcel Thekaekara. Retrieved December 10, 2017, from https://www.theguardian.com/commentisfree/2016/aug/15/india-caste-system-70anniversary-independence-day-untouchables.

Thorat, S., Shyamprasad, K. M., \& Srivastava, R. K. (2007). Report of the committee to enquire into the allegation of differential treatment of SC/ST students in All India Institute of Medical Science, Delhi. Thorat Committee, 2-77.

Thornton, P. H. (2004). Markets from culture: Institutional logics and organizational decisions in higher education publishing. Stanford University Press.

Thornton, P. H., \& Ocasio, W. (2008). Institutional logics. The Sage handbook of organizational institutionalism, 840, 99-128.

Thornton, P. H., Ocasio, W., \& Lounsbury, M. (2012). The institutional logics perspective: A new approach to culture, structure, and process. Oxford University Press on Demand.

Uzzi, B., \& Lancaster, R. (2003). Relational embeddedness and learning: The case of bank loan managers and their clients. Management science, 49(4), 383-399.

Van Luijk, H.J. (1997). Business ethics in Western and Northern Europe: a search for effective alliances. Journal of Business Ethics, 16(14), 1579-1587.

Vissa, B. (2011). A matching theory of entrepreneurs' tie formation intentions and initiation of economic exchange. Academy of Management Journal, 54(1), 137-158.

Weber, E. H. (1905). Tastsinn und gemeingefühl (No. 149). W. Engelmann.

Wilkinson R, Pickett K. 2009. The Spirit Level: Why Equality is Better for Everyone. Penguin Books, London. 
Xavier-Oliveira, E., Laplume, A. O., \& Pathak, S. (2015). What motivates entrepreneurial entry under economic inequality? The role of human and financial capital. Human Relations, 68(7), 1183-1207.

Yadav, S. (2017, October 10). Stand Up India plan slowing down: Only 6\% of bank branches gave loans to SC/STs. Retrieved December 10, 2017, from http://indianexpress.com/article/india/stand-up-india-plan-slowing-down-only-6-of-bankbranches-gave-loans-to-scsts-bad-loans-narendra-modi-4882649/

Zacharias, A., \& Vakulabharanam, V. (2011). Caste Stratification and Wealth Inequality in India. World Development, 39(10), 1820-1833

Zwick-Maitreyi, M., Soundararajan, T., Dar, N., Bheel, R.F., and Balakrishnan, P. (2018) Caste in the United States. A Survey of Caste among South Asian Americans. Equality Labs, USA. 
Figure 1: Economic Inequality Elements and Interrelationships Among Them

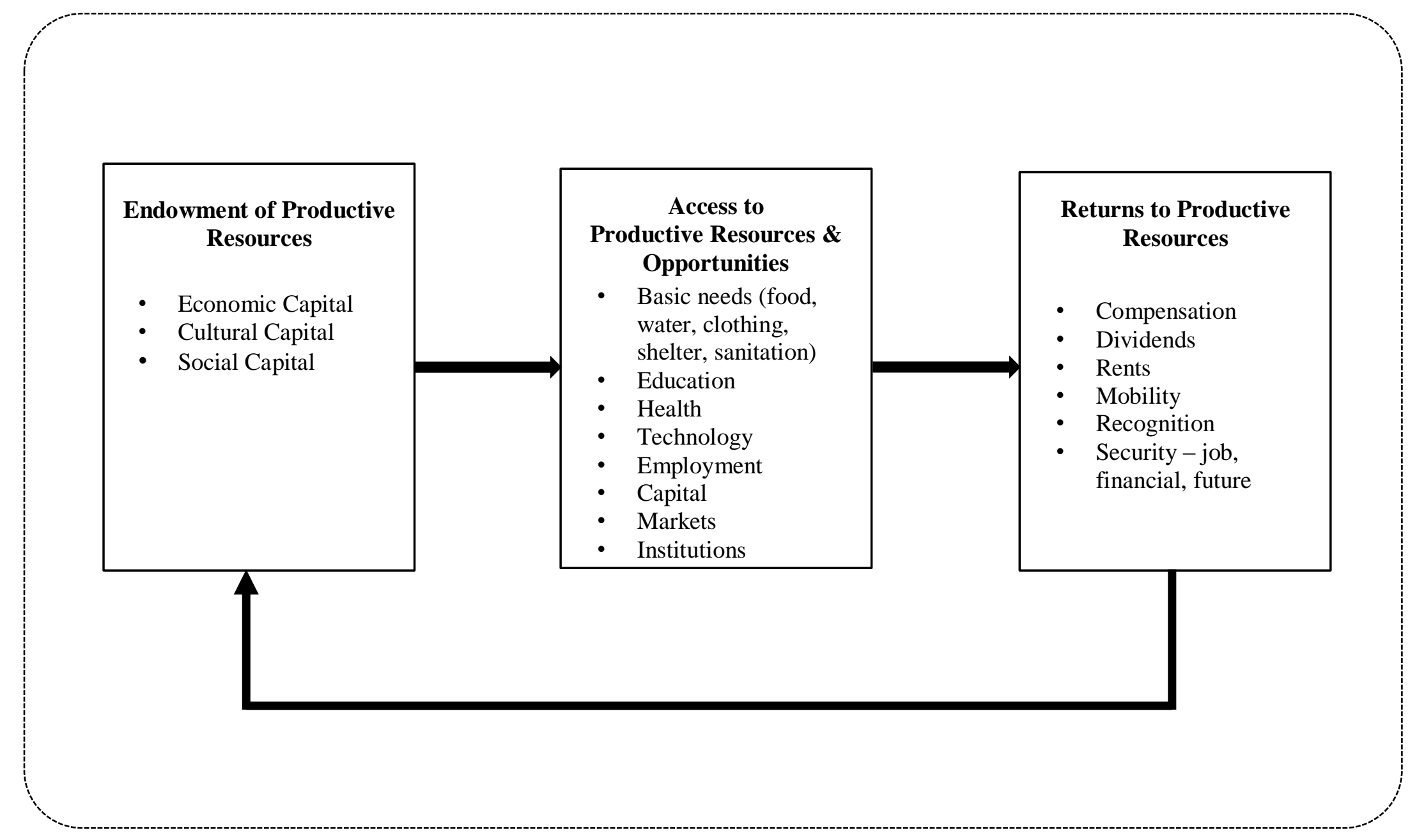

